\section{Orchard Floor Practices Affect Soil Compaction around Young Pecan Trees}

\author{
Wheeler G. Foshee ${ }^{1}$ \\ Department of Horticulture, Auburn University, AL 36849
}

Randy L. Raper ${ }^{2}$

U.S. Department of Agriculture, Agricultural Research Service, National Soil

Dynamics Laboratory, Auburn University, AL 36849

William D. Goff ${ }^{3}$

Department of Horticulture, Auburn University, AL 36849

Michael G. Patterson ${ }^{3}$

Department of Agronomy and Soils, Auburn University, AL 36849

Additional index words. Carya illinoensis, Carya illinoinensis, disking, mowing, soil penetrometer, cone index

Abstract. Orchard floor treatments of total weed control with herbicides, disking, mowing, grass control only with herbicides, and no control of vegetation were maintained in a $3 \times$ 3-m area underneath young pecan [Carya illinoinensis (Wangehn.) K. Koch] trees. Soil compaction in treated areas was compared to heavily trafficked row middles. Mean cone index (CI) readings obtained from a cone penetrometer for the heavily trafficked areas were higher, indicating greater compaction than all other treatments in the $4.7-$ to $11.8-\mathrm{cm}$ soil depth range. Heavily trafficked areas had severe compaction $(>2.0 \mathrm{MPa})$ at the 9.5to 22.9-cm soil depths. Mowed plots had similar CI readings at 14.2- to 54.3-cm depth as those heavily trafficked. The mowed areas had severe compaction at the 14.2- to $22.9-\mathrm{cm}$ depth range. Grass control only with herbicides and plots with no control of vegetation had low CI throughout the soil profile. Disking, grass control, and no control treatments had similar effects, except at the 4.7-cm depth, where disking reduced compaction. An orchard floor management practice that minimized traffic near young trees, but also reduced weed competition, appears to be the best choice.

Pecan production is highly mechanized, with heavy equipment weighing as much as $10,000 \mathrm{~kg}$ passing over an orchard 15 to 30 times annually (Wood and White, 1986). This heavy traffic causes soil compaction, which is detrimental to pecan production (Trouse, 1978). However, there has been limited research to document the degree of soil compaction. Trouse (1978) reported that surface soils in a mature pecan orchard had a bulk density of $1.72 \mathrm{~g} \cdot \mathrm{cm}^{-1}$ and that root development was restricted. Wood and White (1986) found that a onetime disking in a mature orchard resulted in a 35\% increase in cumulative yield for the 4 years following the disking.

Compacted soils reduced root growth and development of landscape trees (Alberty et al., 1984). Compaction decreases water and nutrient infiltration, reduces root growth, decreases water and nutrient uptake, and can decrease

Received for publication 9 Sept. 1996. Accepted for publication 15 Feb. 1997. Alabama Agricultural Experiment Station Journal Series no. 11-965262. We express our thanks to Ronnie McDaniel for maintenance of the planting and Laura G. Sanders for statistical support. The cost of publishing this paper was defrayed in part by the payment of page charges. Under postal regulations, this paper therefore must be hereby marked advertisement solely to indicate this fact.

${ }^{1}$ Former Graduate Research Assistant.

${ }^{2}$ Agricultural Engineer.

${ }^{3}$ Professor. soil oxygen levels (Unger and Kaspar, 1994). The purpose of this study was to determine the degree of soil compaction 9 years after establishment of pecan trees subjected to a variety of orchard floor management practices.
Bareroot 'Desirable' pecan trees were planted in February 1986 on a $9.1 \times 10.7-\mathrm{m}$ spacing and were not irrigated. The experiment was conducted at the Gulf Coast Substation at Fairhope in southwest Alabama on a Malbis fine sandy loam (fine loamy siliceous, thermic Plinthic Paleudults). Treatments were arranged in a randomized complete-block design with four single-tree replications. There were five treatments applied underneath the trees in a $3 \times 3-\mathrm{m}$ area: 1) total weed control with herbicides (TWC), 2) disking once monthly (disking), 3) mowing twice per month (mowing), 4) grass control only with selective herbicides (GCO), and 5) no control of vegetation (NC). A sixth treatment was the heavily trafficked $(\mathrm{HT})$ row middles where vegetation was not controlled.

Lime and fertilizer were applied and incorporated before planting, based on soil analysis. Postplant fertilizer and lime applications were uniformly spread on all plots based on composite leaf and soil samples taken in July to determine the amount to be applied the following season, as based on established recommendations (O'Barr et al., 1989). The plots received an annual application based on these results.

Mowing and disking were performed during the growing season on a 2 - and 4-week schedule, respectively. The TWC and the GCO plots were sprayed with labeled rates of herbicides specific for each during the nine growing seasons (Tables 1 and 2). All herbicides were applied with a tractor-mounted boom-type sprayer using compressed air $(220 \mathrm{kPa})$ as the propellant, delivering a carrier volume of 140 $\mathrm{L} \cdot \mathrm{ha}^{-1}$. All weed control treatments were initially confined to a $3 \times 3-\mathrm{m}$ area around the trees. In the seventh growing season, they were expanded to a $4 \times 4-\mathrm{m}$ area due to tree growth.

At the beginning of the 10th growing sea-

Table 1. Herbicide (active ingredient) treatments for total weed control (TWC) plots.

\begin{tabular}{llr}
\hline \hline $\begin{array}{l}\text { Season no. } \\
\text { and month }\end{array}$ & \multicolumn{1}{c}{ Herbicide } & $\begin{array}{c}\text { Rate } \\
\left(\mathrm{kg}^{2} \cdot \mathrm{ha}^{-1}\right)\end{array}$ \\
\hline Growing season 1 & & \\
March & Postemergence-paraquat & 0.6 \\
& Preemergence-oryzalin & 2.2 \\
June & Postemergence-glyphosate & 3.4 \\
September & Postemergence-paraquat & 0.6 \\
& Preemergence-norflurazon & 2.7 \\
Growing season 2 & & 2.8 \\
April & Preemergence-simazine & 2.2 \\
& Preemergence-oryzalin & 3.4 \\
June & Postemergence-glyphosate & 1.4 \\
September & Postemergence-paraquat & 3.4 \\
& Preemergence-norflurazon & 2.2 \\
Growing seasons 3-9 & & 2.2 \\
April (season 3) & Preemergence-oryzalin & 1.1 \\
April (season 4) & Preemergence-simazine & 3.4 \\
April (season 5) & Postemergence-paraquat \\
April (seasons 6-9) & Preemergence-diuron & 2.2 \\
May & Postemergence-glyphosate & 1.1 \\
July & Postemergence-paraquat & 3.4 \\
September & Preemergence-norflurazon & 0.7 \\
& Postemergence-paraquat &
\end{tabular}

${ }^{2}$ Chemical names of herbicides: paraquat (1,1'-Dimethyl-4,4'-bipyridinium ion), oryzalin (4[dipropylamino]3,5-dinitrobenzenesulfonamide), glyphosate ( $N$-(phosphonomethyl)glycine), norflurazon (4-chloro-5-(methylamino)-2-(3-(trifluoromethyl)phenyl)-3(2H)pyridazinone), simazine (6-chloro- $N, N^{\prime}$ diethyl,1,3,5-triazine-2,4-diamine), diruon ( $N^{\prime}$-(3,4-dichlorophenyl)- $N, N$-dimethylurea). 
son, a soil cone penetrometer (ASAE, 1991) with a base area of $323 \mathrm{~mm}^{2}$, mounted on a John Deere 2955 tractor, was used to determine the penetration resistance of the soil (Fig. 1). According to ASAE (1991), cone index (CI) is defined as the force per unit area required to push the penetrometer through a specified, very small, increment of soil. CI values were then calculated for each depth for which a measure of force was obtained. At each plot, midway between the trunk and the edge of the $3 \times 3-\mathrm{m}$ square, one penetration was made with the three-probed unit. The HT row middles were measured adjacent to each plot for comparison (Fig. 2). CI data were analyzed at selected depths from 1.2 to 68.6 $\mathrm{cm}$. Treatments were compared at the various selected depths with a least significant difference (LSD) test. Soil moisture samples were taken from each treatment at depths of 0 to $15.2 \mathrm{~cm}$ and 15.2 to $30.5 \mathrm{~cm}$.

The entire data set was analyzed with the GLM procedure (SAS Institute, 1990) as a randomized complete-block design. Selected single-degree-of-freedom contrasts were completed along with LSD.

\section{Results and Discussion}

The TWC plots contained less moisture in the 0 - to $15.2-\mathrm{cm}$ depth than all other plots, except HT (Fig. 3). The HT area was lower in moisture than the disked area, possibly, at least partially, because the plots received 64 $\mathrm{mm}$ of rain within $24 \mathrm{~h}$ before measuring. Also, a weed-free surface on the soil would allow this large amount of rain to run off before infiltration could occur. In the 15.2- to $30.5-\mathrm{cm}$ depth zone, the percentage of moisture readings were similar for all plots and ranged from 11.5 to 13.0 .

CIs at the 4.7-, 7.1-, 9.5-, and $11.8-\mathrm{cm}$ depths for the soil in the HT row middles were higher than they were for any of the treatments applied under the trees, indicating more compaction (Table 3 ). At the $9.5-\mathrm{cm}$ depth, the HT area had a CI $>2.0 \mathrm{MPa}$, a level of compaction considered to impede the growth of cotton (Gossypium hirsutum L.) roots (Taylor and Gardner, 1963); these CIs remained $>2.0 \mathrm{MPa}$ down to the 22.9-cm depth (Table 3 ).

The mowing treatment and the HT row middles were similar in that the same grasses were present and both areas were mowed. The row middles, however, had much more traffic, as this was where spray and other equipment normally moved. Some differences in compaction between the mowing treatment and the $\mathrm{HT}$ row middles were observed. The $\mathrm{CI}$ for HT was higher than that for the mowing treatment at the 2.4- to 11.8-cm depths (Table 3). Both the mowed plots and the HT row middles had CIs $>2.0 \mathrm{MPa}$ in the $14.2-$ to $22.9-\mathrm{cm}$ depth range.

The GCO and the NC treatments were similar at all depths analyzed. Therefore, these were pooled into a "cover group" treatment. The cover group treatment generally had lower CIs than any other treatment throughout the soil profile. The cover group treatment only exceeded the 2.0 MPa CI at the 22.9- and 68.6$\mathrm{cm}$ depths. Results for disking were very simi-
Table 2. Herbicide (active ingredient) treatments on grass control only (GCO) plots.

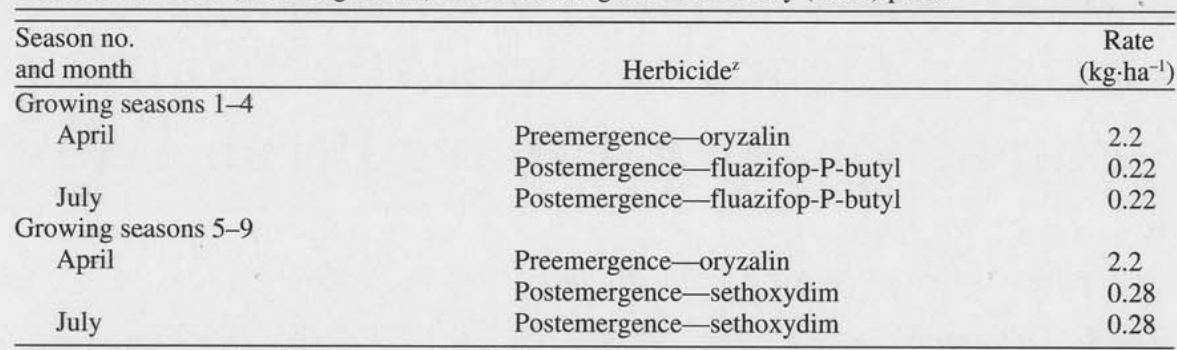

${ }^{7}$ Chemical names of herbicides: oryzalin (4-[dipropyulamino]3,5-dinitrobenzenesulfonamide), fluazifopP-butyl (butyl(R)-2[4-[[5-(trifluoromethyl)-2 pyridinyl]oxy]phenoxy]propanoate), sethoxydim (2-[1(ethoxyimino)butyl]-5-[2-(ethylthio)propyl]-3-hydroxy-2-cyclohexen-1-one).

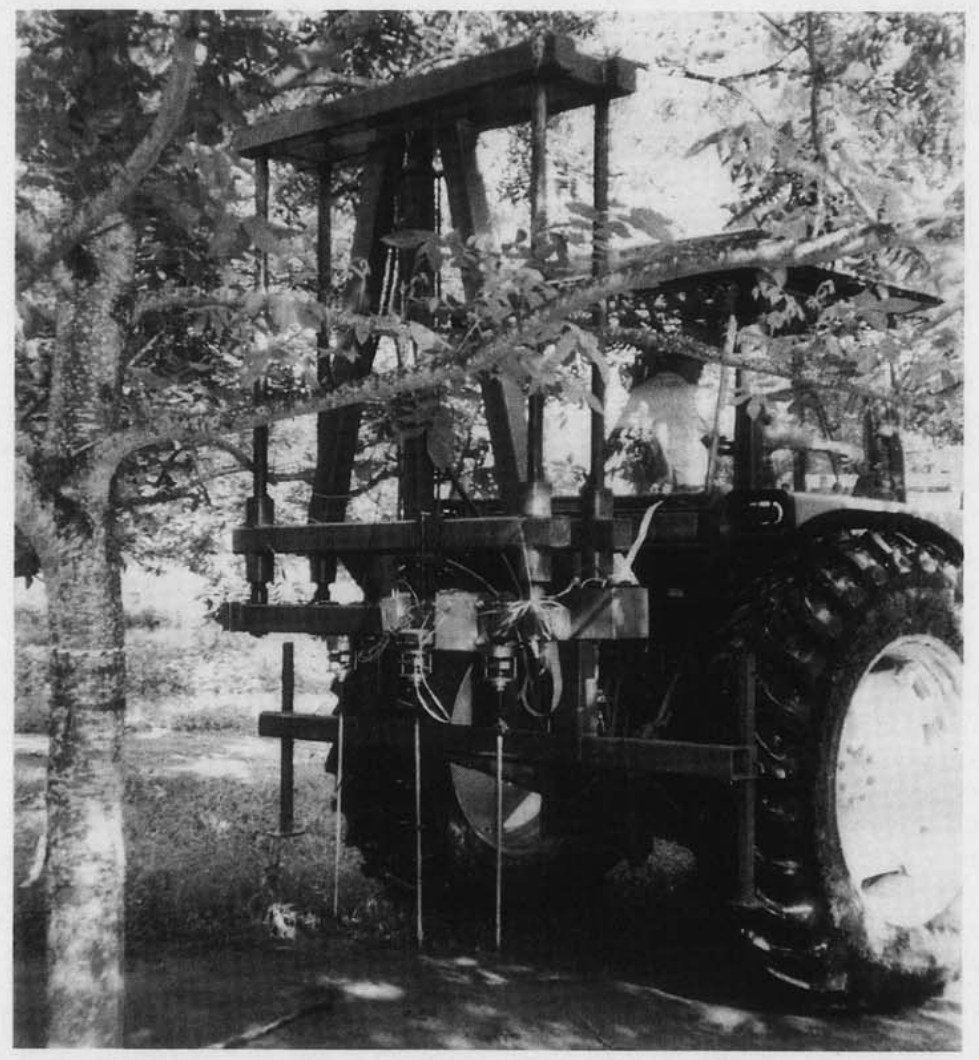

Fig. 1. Soil cone penetrometer (ASAE, 1991) mounted on a John Deere 2955 tractor.
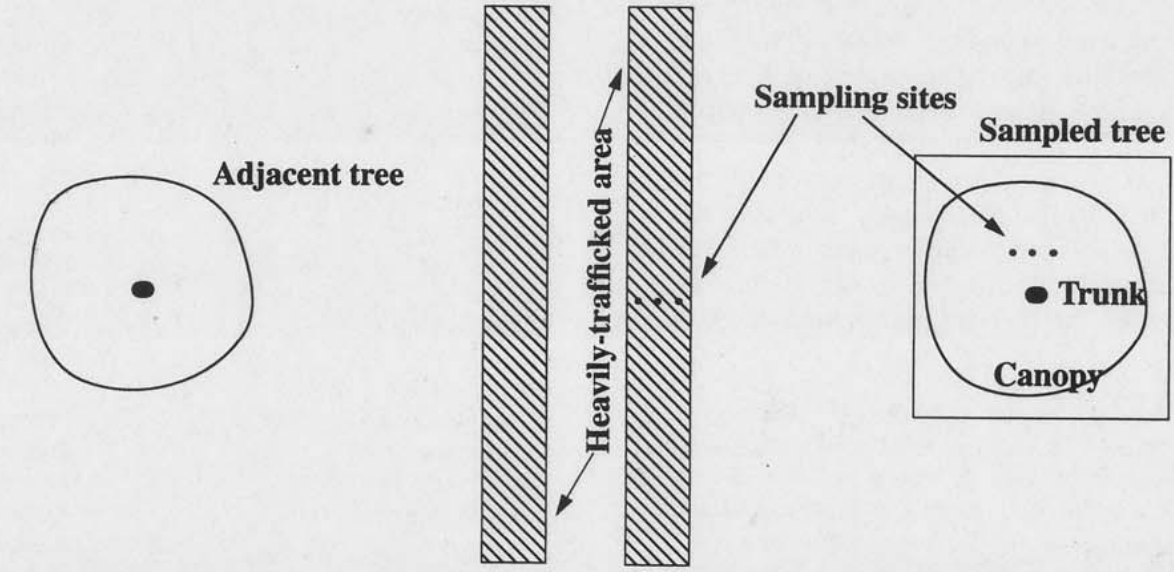

Fig. 2. Diagram of treatments in relation to heavily trafficked row middle and placement of soil cone penetrometer within each plot.

lar to those for the cover group and CI only differed at the $4.7-\mathrm{cm}$ depth, which is within the operating depth of the disk.
The TWC treatment had higher CIs than all others in the $45.7-$ to $61.0-\mathrm{cm}$ depth range (Table 3 ). No differences existed among treat- 


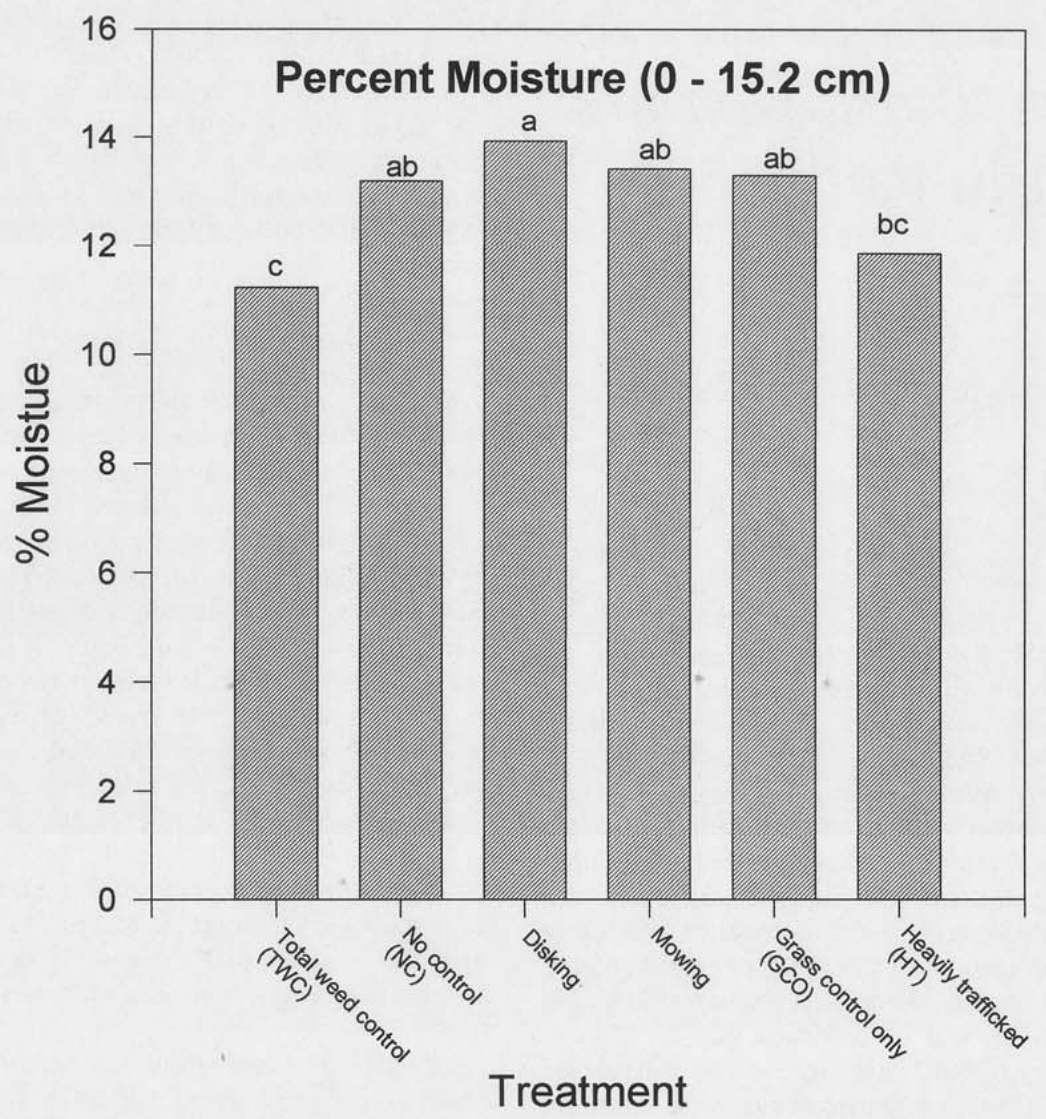

Fig. 3. Percent soil moisture in shallow root zones subject to various orchard floor management practices. Mean separation by LSD $\leq 0.05$; each bar is the mean of four plots plus standard errors.

ments at the $68.6-\mathrm{cm}$ depth. At the $61-\mathrm{cm}$ depth, HT had higher CI values than the cover group or the mowing treatments (Table 3).

Most lateral pecan roots in the southeastern United States on sandy soils are within the top $60 \mathrm{~cm}$ of soil (Woodroof and Woodroof, 1934). Therefore, any compaction in this zone would likely reduce root functions. The HT areas were compacted significantly down to a soil depth of $\approx 23 \mathrm{~cm}$. This type of compaction has been shown to decrease yields in many plants by reducing water infiltration and aeration (Unger and Kaspar, 1994).

Wood and White (1986) showed that in a mature, heavily trafficked pecan orchard, a single disking could temporarily improve the yields. Disking the heavily trafficked areas we measured might alleviate the shallow com- pacted zone, down to a depth of $15 \mathrm{~cm}$, and increase yields. However, repeated disking could cause formation of hardpans beneath the disking depth. This phenomenon has been well documented in row crops systems and can severely reduce growth of plants (Unger and Kaspar, 1994). Compaction was not increased below the disking depth in this study, despite disking at monthly intervals for 9 years during the growing season.

Mowing, which is a common practice in pecan orchards in the Southeast, did increase soil compaction at the $14.2-$ and $15.2-\mathrm{cm}$ depths when compared to TWC (Table 3 ). The values measured in the mowing treatment were $>2 \mathrm{MPa}$ limit, which has been established as detrimental for crop growth (Taylor and Gardner, 1963).
There can be a dramatic increase in the growth and yields from the trees in the TWC treatments as compared to those in other treatments (Patterson et al., 1994). Interestingly, the CI values for TWC were less than the 2 $\mathrm{MPa}$ limit from 1.2 to $45.7 \mathrm{~cm}$ deep. Within this range, much root activity occurs. Plots of this treatment were sprayed with a herbicide sprayer, where the boom extended over the treatment area, but the weight of the equipment was outside the $3 \times 3$-m square, thereby reducing traffic. In contrast, mowing and disking involved traffic moving over the treated areas. The cover group (GCO and $\mathrm{NC}$ ) treatments also had low traffic in the area near the trees, keeping compaction slight, but those trees grew and yielded much less than those in the TWC plots (unpublished data), likely due to weed competition. We hypothesize that total elimination of weed competition in young pecan trees will improve growth. This hypothesis is supported in yet another study where young pecan trees were mulched, had no traffic near trees, and grew better than those treatments with weed competition (Foshee et al., 1996).

\section{Literature Cited}

Alberty, C.A., H.M. Pettett, and D.H. Taylor. 1984. Characterization of soil compaction at construction sites and woody plant response. J. Environ. Hort. 2:48-53.

ASAE Standards. 1991. ASAE S313.1: Soil cone penetrometer. ASAE, St. Joseph, Mich.

Foshee, W.G., W.D. Goff, K.M. Tilt, J.D. Williams, J.S. Bannon, and J.B. Witt. 1996. Organic mulches increase growth of young pecan trees. HortScience 31:811-812.

O'Barr, R.D., M. Smith, G. Taylor, and W.D. Goff. 1989. Pecan nutrition, p. 61-72. In: W.D. Goff, J.R. McVay, and W.S. Gazaway (eds.). Pecan production in the southeast. A guide for growers. Alabama Coop. Ext. Serv., Auburn Univ.

Patterson, M.G. and W.D. Goff. 1994. Effects of weed control and irrigation on pecan (Carya illinoinensis) growth and yield. Weed Tech. 8:717-719.

SAS Institute. 1990. SAS/STAT user's guide. version 6, 4th ed., vol. 2. SAS Inst., Cary, N.C.

Taylor, H.M. and H.R. Gardner. 1963. Penetration of cotton seedling taproots as influenced by bulk density, moisture content, and strength of soil. Soil Sci. 96:153-156.

Trouse, Jr., A.C. 1978. Is traffic affecting pecan production? Pecan South 5:153-156.

Unger, P.W. and T.C. Kaspar. 1994. Soil compaction and root growth: A review. Agron. J. 86:759-766.

Wood, B.W. and A.W. White, Jr. 1986. Influence of disk cultivation and subsoiling on productivity of a mature pecan orchard. HortScience 21:66-68.

Woodroof, I.G. and N.C. Woodroof. 1934. Pecan root growth and development. J. Agr. Res. 49:511-530.

Table 3. Effects of orchard floor management on cone indices (CIs) in rooting zone of young pecan trees at Gulf Coast Substation, Fairhope, Ala.

\begin{tabular}{|c|c|c|c|c|c|c|c|c|c|c|c|c|c|c|}
\hline \multirow{3}{*}{ Treatment } & \multicolumn{14}{|c|}{$\mathrm{CI}(\mathrm{MPa})$} \\
\hline & \multicolumn{14}{|c|}{ Depth $(\mathrm{cm})^{\mathrm{z}}$} \\
\hline & 1.2 & 2.4 & 4.7 & 7.1 & 9.5 & 11.8 & 14.2 & 15.2 & 22.9 & 30.5 & 45.7 & 54.3 & 61.0 & 68.6 \\
\hline$\overline{\mathrm{HT}}$ & 0.17 & $0.44 \mathrm{a}$ & $1.28 \mathrm{a}$ & $1.86 \mathrm{a}$ & $2.06 \mathrm{a}$ & $2.14 \mathrm{a}$ & $2.20 \mathrm{a}$ & $2.25 \mathrm{a}$ & 2.10 & 1.77 & $1.27 \mathrm{~b}$ & $1.68 \mathrm{~b}$ & $2.18 \mathrm{~b}$ & 2.70 \\
\hline Disking & 0.10 & $0.19 b$ & $0.34 \mathrm{~d}$ & $0.67 \mathrm{c}$ & $1.05 \mathrm{c}$ & $1.39 \mathrm{c}$ & $1.74 \mathrm{a}-\mathrm{c}$ & $1.95 \mathrm{ab}$ & 1.94 & 1.78 & $1.00 \mathrm{~b}$ & $1.52 \mathrm{~b}$ & $1.77 \mathrm{bc}$ & 2.34 \\
\hline Cover group ${ }^{y}$ & 0.11 & $0.27 \mathrm{ab}$ & $0.56 \mathrm{c}$ & $0.76 \mathrm{c}$ & $1.01 \mathrm{c}$ & $1.33 \mathrm{c}$ & $1.68 \mathrm{bc}$ & $1.78 \mathrm{ab}$ & 2.18 & 1.66 & $0.99 \mathrm{~b}$ & $1.31 \mathrm{~b}$ & $1.65 \mathrm{c}$ & 2.18 \\
\hline Mowing & 0.08 & $0.24 \mathrm{~b}$ & $0.68 \mathrm{c}$ & $1.07 \mathrm{~b}$ & $1.32 \mathrm{~b}$ & $1.73 \mathrm{~b}$ & $2.16 \mathrm{ab}$ & $2.28 \mathrm{a}$ & 2.29 & 1.69 & $1.03 \mathrm{~b}$ & $1.32 \mathrm{~b}$ & $1.62 \mathrm{c}$ & 2.03 \\
\hline Total weed control & 0.10 & $0.35 \mathrm{ab}$ & $0.91 \mathrm{~b}$ & $1.21 \mathrm{~b}$ & $1.42 \mathrm{~b}$ & $1.60 \mathrm{bc}$ & $1.63 \mathrm{c}$ & $1.63 \mathrm{~b}$ & 1.79 & 1.57 & $1.79 \mathrm{a}$ & $2.29 \mathrm{a}$ & $2.65 \mathrm{a}$ & 2.82 \\
\hline \multicolumn{15}{|l|}{ Analysis of variance } \\
\hline Treatment & 0.0001 & & & & & & & & & & & & & . \\
\hline Depth & 0.0001 & & & & & & & & & & & & & \\
\hline Treatment $\times$ depth & 0.0001 & & & & & & & & & & & & & \\
\hline \multicolumn{15}{|l|}{ By depth } \\
\hline Treatment & 0.5622 & 0.0171 & 0.0001 & 0.0001 & 0.0001 & 0.0001 & 0.0197 & 0.0384 & 0.9097 & 0.9944 & 0.0016 & 0.0010 & 0.0004 & 0.0552 \\
\hline
\end{tabular}

${ }^{\mathrm{z}}$ Mean separation within each column by LSD at $P \leq 0.05$.

y Means for GCO and NC treatments. 